\title{
Sikap atas Produk Tiruan sebagai Mediator Kerentanan Konsumen terhadap Intensi Membeli Produk Fashion Tiruan
}

\author{
ANGGER AGUNG PERMADI \& DEWI SYARIFAH* \\ Fakultas Psikologi Universitas Airlangga
}

\begin{abstract}
ABSTRAK
Penelitian ini bertujuan untuk mengetahui pengaruh kerentanan konsumen terhadap intensi membeli produk fashion tiruan dengan sikap atas produk tiruan sebagai mediator. Laporan MIAP menunjukkan sebagian konsumen di Indonesia kurang memerhatikan keaslian produk ketika akan membeli suatu produk fashion, akibatnya banyak di antara masyarakat yang kemudian membeli produk fashion tiruan. Dampak dari peredaran produk fashion tiruan menyebabkan produsen produk asli hingga pemerintah mengalami kerugian yang cukup besar. Penelitian dilakukan dengan menggunakan kuesioner yang disebar secara online kepada individu yang mengetahui produk fashion tiruan dan berusia 18 tahun ke atas. Hasil penelitian menunjukkan adanya peran mediasi yang signifikan dari sikap atas produk tiruan dalam pengaruh kerentanan konsumen terhadap intensi membeli produk fashion tiruan, serta terjadi mediasi secara parsial dari tiga variabel tersebut.
\end{abstract}

Kata kunci: intensi membeli, kerentanan konsumen, produk fashion tiruan, sikap

\begin{abstract}
This study aims to determine the effect of consumer vulnerability on the intention to buy counterfeit fashion products with attitudes towards counterfeit products as a mediator. The MIAP report shows that some consumers in Indonesia do not pay attention to the authenticity of the product when they are going to buy a fashion product, as a result, many people buy counterfeit fashion products. The impact of the circulation of counterfeit fashion products causes producers of original products to the government to suffer considerable losses. The study was conducted using a questionnaire distributed online to individuals who know about counterfeit fashion products and are aged 18 years and over. The results showed that there was a significant mediating role of attitudes towards counterfeit products in the influence of consumer susceptibility to the intention to buy counterfeit fashion products, and there was a partial mediation of the three variables.
\end{abstract}

Keywords: attitudes, consumer susceptibility, counterfeit fashion product, purchase intention

Buletin Penelitian Psikologi dan Kesehatan Mental (BRPKM), 2021, Vol. 1(1), 892-902

*Alamat korespondensi: Fakultas Psikologi Universitas Airlangga, Kampus B Universitas Airlangga Jalan Airlangga 4-6 Surabaya 60286. Surel: dewi.syarifah@psikologi.unair.ac.id Common Attribution License (CC-BY-4.0) (http://creativecommons.org/licenses/by/4.0), sehingga penggunaan, distribusi, reproduksi dalam media apapun atas artikel ini tidak dibatasi, selama sumber aslinya disitir dengan baik. 


\section{PEN D A H U L U A N}

Organization for Economic Co-operation and Development (1998) menjelaskan, secara teknik kata counterfeiting hanya merujuk pada kasus pelanggaran hak merek dagang, tetapi pada praktiknya istilah tersebut juga mencakup pembuatan barang yang bentuk fisiknya sengaja diserupakan dengan produk asli yang sudah beredar lebih dulu di pasaran. Barang tiruan sendiri dikalangan masyarakat Indonesia dikenal dengan istilah KW atau produk kwalitas (Sani \& Nurtjahyanti, 2016). Menurut Statista Research Department penjualan produk fashion tiruan di seluruh dunia pada tahun 2020 telah mencapai angka 26,3 miliar euro.

Perdagangan barang tiruan telah menjadi suatu bisnis yang cukup menguntungkan, di kawasan Asia miliaran dollar hilang setiap tahunnya akibat dari pembuatan dan penjualan barang tiruan yang mencakup beberapa negara antara lain, Tiongkok, Hong Kong, Korea Selatan, dan beberapa negara Asia Tenggara termasuk Indonesia (Ting dkk., 2016). Masyarakat Indonesia Anti Pemalsuan (MIAP) menyebutkan kerugian ekonomi tingkat nasional pada tahun 2014 telah mencapai angka 41,58 triliun rupiah serta kerugian dari pajak tidak langsung yang ditanggung oleh pemerintah mencapai angka 424 miliar rupiah dari peredaran produk fashion tiruan (Kemenperin, 2014). Kemudian, menurut Rahmat Gobel sebagai menteri perdagangan pada tahun 2015 menyebutkan sekitar 40 persen produk yang beredar di Indonesia adalah produk KW.

Produk fashion seperti pakaian, sepatu, tas, dan berbagai macam aksesoris lainnya sudah menjadi kebutuhan pokok masyarakat selain makanan dan tempat tinggal (Efendi \& Baidun, 2019). Status simbolik yang terdapat pada suatu barang, akses menuju tempat membeli barang yang mudah, hingga harga barang yang murah dari produk aslinya menjadi alasan konsumen lebih memilih produk tiruan (Siham \& Pierre, 2012). Kebutuhan untuk diterima dan menjadi sama dengan orang lain yang terdapat dalam diri individu menjadi salah satu penyebab mereka berusaha mengikuti gaya hidup yang ada disekitarnya dengan membeli barang yang sedang diminati oleh masyarakat luas. Hal tersebut bertujuan sebagai wujud pemenuhan akan penghargaan dan meningkatkan status identitas dirinya di lingkungan sekitar (Chrisnawati \& Sri, 2011).

Efendi dan Baidun (2019) menjelaskan sebagian konsumen cenderung memiliki motivasi yang tinggi untuk membeli produk fashion tiruan karena mengikuti pendapat orang lain seperti keluarga, teman, idola, hingga sekadar mengikuti tren fashion yang sedang berkembang di masyarakat. Banyaknya permintaan dan kesadaran masyarakat yang masih kurang terhadap produk fashion tiruan membuat peredaran produk tersebut terus meningkat dan dapat memicu konsumen untuk memunculkan perilaku pembelian terhadap produk fashion tiruan (Andyna, 2020).

Proses dalam perilaku membeli menjadi suatu fenomena yang menarik, sebab terdapat proses kognitif pada setiap individu yang selanjutnya menghasilkan intensi untuk memunculkan suatu perilaku. Meski terdapat pertentangan di masyarakat, setiap individu akan memiliki penilaian tersendiri dalam menyikapi produk fashion tiruan. Ajzen (1991) dalam theory of planned behavior menyebutkan intensi sebagai faktor yang paling kuat untuk memprediksi munculnya suatu perilaku pada individu. Intensi sendiri merupakan bagaimana cara individu menampilkan perilaku dan sebesar apa usaha yang akan dilakukan untuk mewujudkan suatu perilaku tersebut. Serta, intensi merupakan kecenderungan yang bersifat subjektif pada individu dan memungkinkan untuk membentuk suatu perilaku tertentu (Ajzen, 2005). Dalam hal ini keputusan konsumen dalam proses pembelian dapat dipengaruhi oleh intensinya, semakin kuat intensi konsumen terhadap suatu produk, maka semakin tinggi kemungkinan perilaku membeli muncul. 
Menurut Ajzen (1991) terdapat tiga faktor yang dapat memengaruhi intensi pada individu sebelum memunculkan perilaku yakni sikap terhadap perilaku, norma subjektif, dan persepsi kontrol perilaku. Sikap terhadap perilaku merupakan sejauh mana individu memiliki penilaian baik atau buruk pada suatu perilaku atau objek tertentu. Jika individu berkeyakinan bahwa konsekuensi atas perilaku yang akan dilakukan cenderung positif, maka individu akan memiliki sikap yang baik terhadap perilaku tersebut. Oleh sebab itu, individu dengan sikap positif terhadap suatu perilaku memiliki kecenderungan untuk melakukan perilaku tersebut (Fishbein dkk., 1975).

Matos, dkk (2007) juga menyebutkan sikap individu terhadap produk dapat menjadi faktor yang memengaruhi intensi pada individu untuk melakukan perilaku pembelian. Serta attitude toward counterfeit product (sikap atas produk tiruan) yang merupakan evaluasi konsumen terhadap barang tiruan menjadi faktor penting terhadap intensi konsumen untuk memunculkan perilaku membeli barang tiruan. Beberapa penelitian sebelumnya menunjukkan hubungan positif antara sikap atas produk tiruan dengan intensi membeli. Penelitian yang dilakukan oleh Wang, dkk (2005) mengenai intensi membeli perangkat lunak bajakan menunjukkan sikap atas produk bajakan berpengaruh secara positif terhadap intensi membeli.

Kemudian pada penelitian yang dilakukan oleh Cheng dkk.(2011) mengenai intensi membeli produk tiruan menunjukkan sikap atas produk tiruan berpengaruh secara positif terhadap intensi membeli. Konsumen dengan penilaian positif atas atribut yang terdapat pada produk tiruan, seperti harga produk yang terjangkau, maka konsumen akan memiliki sikap positif terhadap produk tiruan. Selanjutnya, dari sikap positif tersebut dapat mendorong intensi konsumen untuk memunculkan perilaku membeli produk fashion tiruan. Sebaliknya, jika konsumen memiliki penilaian negatif atas atribut yang terdapat pada produk tiruan, seperti kualitas bahan yang digunakan, maka dapat terbentuk sikap negatif terhadap produk tiruan (Ajzen, 1991).

Schiffman dan Kanuk mengungkapkan bahwa, intensi membeli produk fashion tiruan pada konsumen dapat terbentuk melalui pencarian informasi dari lingkungan eksternal seperti orang terdekat hingga kepercayaan konsumen maupun dari pengalaman pribadi (Sani \& Nurtjahyanti, 2016). Kemudian jika konsumen merasa informasi yang telah dikumpulkan dinilai cukup, maka proses selanjutnya adalah penilaian dan evaluasi, serta membuat keputusan apakah akan memunculkan perilaku membeli atau tidak (Lin \& Lin, 2007). Konsumen yang membutuhkan informasi dan identifikasi terlebih dahulu sebelum membeli suatu produk, serta berusaha untuk menyesuaikan dengan harapan orang lain merupakan konsumen dengan kerentanan yang tinggi akan pengaruh sosial (Iskandar, 2015).

Bearden, dkk (1989) menjelaskan kerentanan konsumen akan perngaruh sosial merupakan kebutuhan individu untuk dapat seperti orang lain atau meningkatkan citra dirinya dihadapan orang lain dengan mendapatkan dan menggunakan suatu produk atau merek, serta keinginan untuk menyesuaikan dengan harapan orang lain dalam keputusan pembelian, dan kecenderungan untuk mempelajari produk dengan melakukan pengamatan maupun dengan mencari informasi dari orang lain (Bearden dkk., 1989).

Kemudian hasil dari pencarian informasi dan identifikasi tersebut menjadi acuan bagi konsumen untuk melakukan penilaian dan evaluasi untuk menentukan sikapnya terhadap suatu produk sebelum membuat keputusan pembelian. Pada produk tiruan, jika berdasarkan pencarian informasi dan identifikasi individu mendapatkan hasil bahwa produk tiruan tidak disukai di lingkungan sekitarnya dan tidak direkomendasikan oleh orang lain, mereka cenderung membentuk evaluasi dan penilaian yang negatif pada individu terhadap produk tiruan. Selanjutnya, jika berdasarkan pencarian informasi dan identifikasi individu mendapatkan hasil bahwa produk tiruan banyak disukai dan digunakan di lingkungan sekitarnya dan mendapat rekomendasi dari orang lain, mereka cenderung membentuk 
evaluasi dan penilaian yang positif pada konsumen terhadap produk tiruan. Salahian (2016) menyebutkan beberapa literatur menunjukkan bahwa produk tiruan bukan merupakan produk legal dan tidak memberikan kesan yang baik dimata orang lain. Sehingga konsumen dengan kerentanan yang tinggi akan pengaruh sosial cenderung memiliki sikap tidak menyukai terhadap produk tiruan. Penelitian yang dilakukan oleh Wang, dkk (2005) mengenai intensi membeli perangkat lunak bajakan menunjukkan hasil bahwa kerentanan normatif konsumen memengaruhi sikap secara negatif, yang kemudian konsumen dengan sikap negatif tersebut tidak memunculkan intensi untuk membeli produk perangkat lunak bajakan.

Namun, penelitian lainnya yang dilakukan oleh Salahian (2016) menunjukkan kerentanan konsumen berpengaruh secara positif terhadap intensi membeli VCD/DVD bajakan dengan sikap atas produk bajakan sebagai mediator. Hal tersebut menunjukkan bahwa konsumen yang rentan cenderung memiliki sikap positif terhadap produk bajakan yang kemudian mendorong intensi konsumen untuk membeli VCD/DVD bajakan. Berdasarkan penelitian yang telah disebutkan sebelumnya kerentanan konsumen memiliki pengaruh terhadap sikap atas produk, serta sikap atas produk akan mengarahkan intensi membeli pada konsumen untuk memunculkan perilaku pembelian. Kemudian, penelitian ini bertujuan untuk mengetahui apakah terdapat pengaruh kerentanan konsumen terhadap intensi membeli produk fashion tiruan dengan sikap atas produk tiruan sebagai mediator, yang hasilnya akan memberikan gambaran mengenai hubungan dan pengaruh kerentanan konsumen terhadap sikap konsumen atas produk tiruan, serta intensi untuk membeli produk fashion tiruan.

\section{E T ODE}

\section{Desain Penelitian}

Penelitian ini menggunakan pendekatan kuantitatif yang merupakan metode penelitian dengan menggunakan data dalam bentuk angka, kemudian data tersebut diolah menggunakan statistik. Pada penelitian ini teknik pengumpulan data menggunakan metode survei dengan menyebarkan kuesioner kepada partisipan penelitian, serta mencatat jawaban yang diberikan oleh partisipan tanpa memanipulasi situasi maupun kondisi yang ada. Metode survei merupakan teknik pengumpulan data dalam penelitian kuantitatif dengan memberikan beberapa pertanyaan yang sama kepada beberapa orang yang kemudian dilakukan pencatatan dari jawaban yang diberikan (Neuman, 2007). Pendekatan dan metode dalam penelitian ini dilakukan untuk menguji seberapa besar pengaruh kerentanan konsumen terhadap intensi membeli dengan sikap atas produk tiruan sebagai variabel mediator.

\section{Partisipan}

Partisipan dalam penelitian adalah individu yang mengetahui produk tiruan dan memiliki usia minimal 18 tahun. Penelitian ini berkaitan dengan produk fashion tiruan, sehingga pengetahuan mengenai produk fashion tiruan diperlukan untuk memberikan gambaran mengenai pandangan masyarakat terhadap produk fashion tiruan. Hal tersebut dilakukan dengan memberikan penjelasan mengenai apa yang dimaksud dengan produk fashion tiruan beserta beberapa jenis dari produk fashion tiruan yang terdapat dalam kuesioner sebelum melakukan pengisian. Selanjutnya, individu dengan usia 18 tahun ke atas yang merupakan individu yang telah dianggap mampu mempertimbangkan terlebih dahulu sebelum melakukan suatu perilaku. Sebab diusia tersebut segala bentuk perbuatan individu dapat dipertanggungjawabkan secara hukum dan telah dianggap dewasa menurut UU RI No. 1 tahun 1974. Hurlock dalam Haqi (2019) menyebutkan bahwa individu dengan usia 18 tahun keatas lebih banyak melakukan penyesuaian diri dengan lingkungan sekitar, memiliki keinginan untuk diterima dalam 
kelompok-kelompok sosial dan ekonomi, serta memiliki tanggung jawab mengenai hak dan kewajibannya sebagai warga negara.

Kemudian, metode non-probability sampling dipilih sebab populasi dari penelitian belum diketahui, serta pertimbangan mengenai keterbatasan waktu, biaya, dan tenaga dari peneliti. Kemudian, teknik convenience sampling digunakan agar peneliti dapat memilih responden sesuai dengan kriteria berdasarkan siapa saja yang secara kebetulan muncul dan bersedia mengisi kuesioner survei penelitian (Neuman, 2007). Ukuran sampel pada penelitian ini dihitung menggunakan aplikasi $G^{*}$ Power 3.1.9.4. Teknik a priory power analysis dengan statistical test: linier multiple regression: Fixed Model, $R^{2}$ deviation from zero. Teknik tersebut digunakan untuk mengetahui ukuran sampel yang diperlukan dalam penelitian. Kemudian, mendeteksi ukuran effect size sebesar 0,15 dengan statistical power(1- $\beta$ ) sebesar 0.95(95\%) dan alpha sebesar 0,05(5\%) serta jumlah prediktor sebanyak 2. Berdasarkan hasil dari perhitungan tersebut, jumlah sampel yang dibutuhkan dalam penelitian ini sebesar 107 responden.

Partisipan yang didapatkan dalam penelitian ini sebanyak 140 orang berdasarkan hasil kuesioner yang telah disebarkan secara online. Kemudian, rata-rata usia partisipan dalam penelitian ini adalah $M_{\text {usia }}=29,08$ dan $S D_{\text {usia }}=10,27$, sebanyak 60 persen partisipan didominasi oleh perempuan. Pendidikan terakhir partisipan dalam penelitian ini 45 persen didominasi oleh sarjana, serta untuk status perkerjaan sebanyak 32,1 persen merupakan karyawan swasta, yang selanjutnya diikuti oleh mahasiswa sebanyak 28.6 persen.

\section{Pengukuran}

Intensi Membeli pada penelitian ini menggunakan alat ukur yang dikembangkan oleh Wang, dkk (2005) yang telah dilakukan translasi dan adaptasi oleh peneliti sehingga lebih fokus pada konteks produk tiruan. Terdapat 4 aitem favourable dalam alat ukur ini dengan menggunakan skala likert yang memiliki respon 1 "Sangat Tidak Setuju", 2 "Tidak Setuju”, 3 "Netral", 4 "Setuju”, 5 "Sangat Setuju". Dengan koefisien reliabilitas yang cukup baik $(\alpha=.86)$.

Sikap atas produk tiruan pada penelitian ini menggunakan alat ukur yang dikembangkan oleh Cheng, dkk (2011) yang telah dilakukan translasi dan adaptasi oleh peneliti. Terdapat 8 aitem favourable dalam alat ukur ini dengan menggunakan skala likert yang memiliki respon 1 "Tidak Setuju", 2 "Agak Tidak Setuju”, 3 "Netral”, 4 "Agak Setuju”, 5 "Setuju”. Dengan koefisien reliabilitas yang cukup baik $(\alpha=.86)$.

Kerentanan Konsumen pada penelitian ini menggunakan alat ukur yang dikembangkan oleh Wang, dkk (2005) yang telah dilakukan translasi dan adaptasi oleh peneliti sehingga lebih fokus pada konteks produk tiruan. Terdapat 8 aitem favourable dalam alat ukur ini dengan menggunakan skala likert yang memiliki respon 1 "Sangat Tidak Setuju", 2 "Tidak Setuju", 3 "Netral", 4 "Setuju", 5 "Sangat Setuju". Dengan koefisien reliabilitas pada dua subskala kerentanan konsumen yaitu $(\alpha=.70$, dan $\alpha=.76)$.

Uji validitas tiga alat ukur dalam penelitian ini menggunakan bantuan expert judgement dengan uji content validity, yakni melihat apakah isi konten dalam alat ukur telah merepresentasikan definisi dari konstrak yang hendak diukur (Neuman, 2007). Sebelum melakukan analisis data peneliti terlebih dahulu melakukan uji asumsi antara lain, uji normalitas untuk mengetahui apakah jenis data terdistribusi secara normal sehingga peneliti dapat menentukan teknik analisis yang digunakan yakni analisis parametrik atau non-parametrik. Selanjutnya, dilakukan uji linieritas untuk mengetahui apakah terdapat hubungan yang linier antar variabel. Kemudian dilakukan uji heteroskedastisitas yang bertujuan untuk menguji apakah terdapat atau tidak ketidaksamaan varians dari residual satu pengamatan ke pengamatan yang lainnya dengan model regresi (Saputra, 2009). 


\section{Analisis Data}

Pada penelitian ini teknik analisis data menggunakan analisis regresi berupa analisis jalur dengan tujuan untuk menganalisis hubungan sebab-akibat antara satu atau beberapa variabel. Analisis jalur juga dapat digunakan untuk menelusuri beberapa jalur yang berpengaruh terhadap suatu variabel (Yudiaatmaja, 2021). Kemudian melakukan uji sobel test untuk mengetahui signifikansi efek tidak langsung variabel mediator $(\mathrm{Z})$ atas variabel independen $(\mathrm{X})$ terhadap variabel dependen $(\mathrm{Y})$. Penelitian ini menggunakan bantuan program SPSS 22.0 for windows untuk keperluan analisis data.

\section{HAS I L P EN ELITIAN}

\section{Analisis Deskriptif}

Berdasarkan analisis deskriptif, diketahui jumlah data setiap variabelnya adalah 140. Pada variabel kerentanan konsumen diperoleh (Min=15; Max=45; $M=26,54)$, yang menunjukkan rata-rata partisipan memiliki kerentanan konsumen pada kategori sedang. Selanjutnya, pada variabel sikap atas produk tiruan diperoleh sebesar (Min=8; $M a x=38 ; M=21,21$ ) yang menunjukkan rata-rata partisipan cukup menyukai produk tiruan. Pada variabel intensi membeli didapatkan (Min=4; $M a x=20 ; M=9,15)$ yang menunjukkan rata-rata partisipan cenderung ingin membeli produk fashion tiruan.

\section{Uji Asumsi}

Uji normalitas melalui uji statistik kolmogorov-smirnov yakni jika nilai signifikansi lebih dari 0,05 maka dapat disimpulkan bahwa data memiliki distribusi normal (Pallant, 2016). Pada penelitian ini hasil uji normalitas residual menunjukkan nilai signifikansi sebesar 0,200. Nilai residual tersebut lebih dari 0,05 yang menunjukkan bahwa distibusi data memenuhi asumsi normalitas.

Uji Linearitas dalam penelitian ini menggunakan grafik scatterplot, yakni dua variabel dapat dikatakan linear ketika persebaran data membentuk garis lurus dan tidak membentuk garis kurva (Pallant, 2016). Berdasarkan grafik scatterplot menunjukkan terdapat hubungan linear antara kerentanan konsumen dengan sikap atas produk tiruan yang membentuk pola garis lurus dari kiri bawah ke kanan atas. Selanjutnya, grafik scatterplot juga menunjukkan hubungan linear antara kerentanan konsumen dengan intensi membeli yang membentuk pola garis lurus dari kiri bawah ke kanan atas. Kemudian pada variabel sikap atas produk tiruan dengan intensi membeli juga menunjukkan hubungan linear yang membentuk pola garis lurus dari kiri bawah ke kanan atas.

Uji heterokedastisitas pada penelitian ini menggunakan uji glejser dengan ketentuan, jika nilai signifikansi lebih kecil dari 0,05 maka terjadi gejala heterokedastisitas, sebaliknya jika nilai signifikansi lebih dari 0,05 maka tidak terjadi gejala heterokedastisitas (Al-Baroroh, 2019). Hasil uji heterokedastisitas diketahui nilai signifikansi dari variabel dalam penelitian ini pada kerentanan konsumen sebesar 0,53, sikap atas produk tiruan sebesar 0,06, dan intensi membeli sebesar 0,19. Hasil tersebut menunjukkan tidak terjadi gejala heterokedastisitas.

\section{Uji Regresi}

Sebelum melakukan uji mediasi terlebih dahulu dilakukan uji regresi untuk mengetahui adanya pengaruh dari variabel independen terhadap variabel mediator, variabel mediator terhadap variabel dependen, dan variabel independen terhadap variabel dependen. Hasil analisis regresi linier pada kerentanan konsumen diketahui dapat menjelaskan data $\left(F(1,138)=6,423 ; p=0,012 ; R^{2}=0,044\right)$ dan kerentanan konsumen mampu menjelaskan variasi sikap atas produk tiruan sebesar 4,4 persen. 
Kemudian nilai $p$ pada model ini sebesar 0,012 yang menunjukkan adanya pengaruh signifikan dari kerentanan konsumen terhadap sikap atas produk tiruan.

Hasil uji regresi linier selanjutnya pada sikap atas produk tiruan dapat menjelaskan data $\left(F(1,138)=437,597 ; p<0,001 ; R^{2}=0.760\right)$ dan sikap atas produk tiruan mampu menjelaskan variasi intensi membeli produk fashion tiruan sebesar 76 persen. Pada model tersebut nilai $p$ yang diperoleh sebesar 0,001 yang menunjukkan adanya pengaruh signifikan sikap atas produk tiruan terhadap intensi membeli produk fashion tiruan. Kemudian hasil uji regresi pada kerentanan konsumen dapat menjelaskan data $\left(F(1,138)=15,100 ; p<0,001 ; R^{2}=0,099\right)$ dan kerentanan konsumen mampu menjelaskan variasi intensi membeli produk fashion tiruan sebesar 9,9 persen, serta diketahui nilai $p$ pada model tersebut sebesar 0,001 yang menunjukkan terdapat perngaruh signifikan kerentanan konsumen terhadap intensi membeli produk fashion tiruan.

Pada pengaruh kerentanan konsumen terhadap sikap atas produk tiruan (jalur a) menunjukkan nilai koefisien $(\beta=0,211 ; S E=0,112 ; p=0,012)$, pengaruh sikap atas produk tiruan terhadap intensi membeli (jalur b) menunjukkan nilai koefisien $(\beta=0,872 ; S E=0,021 ; p<0,001)$, dan pengaruh langsung kerentanan konsumen terhadap intensi membeli (jalur c') menunjukkan nilai koefisien $(\beta=0,314 ; S E=0,054$; $p<0,001)$. Sehingga diketahui pengaruh tidak langsung (jalur $\left.\mathrm{a}^{*} \mathrm{~b}\right)$ menunjukkan nilai koefisien sebesar 0,184 . Kemudian pengaruh total (jalur c) dapat diketahui melalui perhitungan (jalur c'+(a*b)) yang menunjukkan nilai koefisien sebesar 0,498. Serta, seluruh jalur variabel menunjukkan hasil yang signifikan $p<0,05$.

Uji Mediasi

Setelah melakukan analisis regresi selanjutnya dilakukan uji mediasi dengan sobel test untuk mengetahui signifikansi pengaruh tidak langsung variabel independen ke variabel dependen melalui variabel intervening atau mediator (Preacher \& Hayes, 2004).

Hasil uji sobel test diketahui $(Z=2,5253 ; p=0,011)$ yang menunjukkan bahwa terdapat signifikansi efek tidak langsung dari kerentanan konsumen terhadap intensi membeli melalui sikap atas produk tiruan. Berdasarkan hasil analisis regresi dan uji sobel test dapat disimpulkan sikap atas produk tiruan memediasi pengaruh kerentanan konsumen terhadap intensi membeli produk fashion tiruan secara parsial. Mediasi parsial terjadi ketika pengaruh langsung $\mathrm{X}$ terhadap $\mathrm{Y}$ signifikan dan pengaruh $\mathrm{X}$ terhadap Y melalui mediator juga signifikan (MacKinnon dkk., 2007).

\section{I S K U S I}

Berdasarkan analisis regresi linear sederhana dapat diketahui bahwa kerentanan konsumen memiliki pengaruh yang signifikan terhadap sikap atas produk tiruan. Dapat disimpulkan, semakin tinggi kerentanan konsumen maka semakin positif sikap konsumen atas produk tiruan. Hasil penelitian ini mendukung penelitian sebelumnya yang dilakukan oleh Salahian (2016) mengenai produk VCD/DVD bajakan yang menunjukkan hasil bahwa kerentanan konsumen berpengaruh signifikan terhadap sikap atas VCD/DVD bajakan.

Ketika konsumen memiliki sedikit pengetahuan mengenai suatu produk tertentu maka konsumen akan berusaha untuk mencari informasi dari orang lain yakni melalui teman, keluarga, kerabat, hingga orang yang memiliki pengetahuan lebih mengenai suatu produk (Saputra, 2009). Serta, keinginan konsumen untuk menyesuaikan dengan harapan orang lain membuat individu berusaha mengidentifikasi produk apa yang banyak disukai oleh orang lain. Produk tiruan sendiri cenderung cukup diminati oleh masyarakat Indonesia (Handayani, 2016). Sehingga, kemungkinan besar berdasarkan informasi yang 
didapat konsumen mendapat rekomendasi dari orang lain untuk membeli produk tiruan, serta hasil identifikasi yang menunjukkan banyak orang menyukai produk tiruan akan memengaruhi penilaian dan evaluasi konsumen yang positif terhadap produk tiruan.

Selanjutnya, penelitian ini menguji adanya pengaruh sikap atas produk tiruan terhadap intensi membeli produk fashion tiruan. Dalam penelitian ini melalui analisis regresi linear menunjukkan hasil bahwa sikap atas produk tiruan memiliki pengaruh terhadap intensi membeli produk fashion tiruan Hasil tersebut didukung oleh penelitian sebelumnya yang dilakukan oleh Cheng, dkk (2011) mengenai adanya pengaruh sikap atas produk tiruan, norma subjektif, dan persepsi kontrol perilaku terhadap intensi membeli produk tiruan. Serta, konsisten dengan hasil penelitian sebelumnya oleh Wang, dkk (2005) mengenai intensi membeli perangkat lunak bajakan.

Kemudian dalam penelitian lainnya mengenai produk bajakan, menunjukkan hasil bahwa sikap atas produk bajakan memiliki pengaruh yang signifikan terhadap intensi membeli produk bajakan (Saputra, 2009). Pada penelitian ini konsumen yang memiliki evaluasi positif mengenai atribut pada produk tiruan cenderung memiliki minat untuk membeli produk fashion tiruan dan begitu pula sebaliknya. Fishbein, dkk (1975) mengungkapkan sikap dinilai cukup kuat dalam memprediksi intensi pada individu, serta sikap dalam banyak literatur pemasaran ditemukan dapat memengaruhi keinginan individu untuk memunculkan suatu perilaku.

Kemudian penelitian ini juga menguji apakah terdapat peran mediasi dari variabel sikap atas produk tiruan, dengan melakukan uji sobel test dan menunjukkan hasil bahwa terdapat efek mediasi yang siginifikan dari sikap atas produk tiruan pada pengaruh kerentanan konsumen terhadap intensi membeli produk fashion tiruan. Sehingga, dalam penelitian ini terdapat pengaruh tidak langsung dari variabel X terhadap variabel Y melalui variabel mediator. Schiffman dan Kanuk dalam Sani \& Nurtjahyanti (2016) menjelaskan bahwa intensi membeli dapat terbentuk melalui pencarian informasi dari orang lain maupun dari pengalaman pribadi.

Setelah informasi yang didapat telah cukup, konsumen akan memulai proses penilaian dan evaluasi mengenai produk yang akan dibeli, yang selanjutnya dapat membentuk intensi individu untuk membeli suatu produk (Lin \& Lin, 2007). Dalam penelitian ini proses pencarian informasi dan identifikasi terdapat dalam kerentanan konsumen yang selanjutnya hasil dari proses tersebut memengaruhi penilaian dan evaluasi konsumen terhadap suatu produk yang menghasilkan sikap menyukai maupun tidak menyukai terhadap suatu produk, kemudian sikap tersebut dapat membentuk intensi pada konsumen untuk melakukan pembelian.

Pada konteks yang berbeda, hasil penelitian ini terdapat perbedaan dengan penelitian yang dilakukan Wang, dkk (2005) dan Saputra (2009) mengenai faktor-faktor yang memengaruhi intensi membeli perangkat lunak bajakan melalui sikap atas produk bajakan. Dalam penelitian tersebut kerentanan konsumen memiliki pengaruh secara negatif terhadap sikap atas produk bajakan dan intensi membeli produk bajakan. Sedangkan, dalam penelitian ini kerentanan konsumen berpengaruh secara positif terhadap sikap atas produk tiruan dan intensi membeli produk fashion tiruan, yakni semakin tinggi kerentanan yang dimiliki konsumen, maka konsumen semakin menyukai produk tiruan, serta cenderung memiliki intensi untuk membeli produk fashion tiruan. Wang, dkk (2005) menjelaskan penggunaan perangkat lunak bajakan pada konsumen terkadang hanya untuk mencoba perangkat lunak yang baru, serta ketersediaan informasi dan akses yang terbatas terhadap perangkat lunak, dan literasi komputer yang rendah. Pada produk tiruan orang akan tertarik dan menggunakan produk tiruan untuk mempertahankan status sosial mereka di masyarakat, mudah dijangkau keteserdiaannya, serta untuk mengikuti tren yang berkembang (Kasuma dkk., 2020). 
Penelitian yang dilakukan oleh Masyarakat Indonesia Anti Pemalsuan (2014) menjelaskan sebagian konsumen di Indonesia kurang memerhatikan keaslian produk ketika akan membeli suatu produk fashion, akibatnya banyak diantara masyarakat yang kemudian membeli produk fashion tiruan. Kemudian pada penelitian yang sama menunjukkan terdapat kerugian yang dialami produsen produk asli dari peredaran produk fashion tiruan yakni sebesar 2,3 triliun rupiah, kemudian dari peredaran produk software palsu sebesar 186 miliar rupiah. Selanjutnya, kerugian yang dialami oleh pemerintah dari potensi perolehan pajak dari produk fashion tiruan sebesar 192 miliar rupiah, serta dari produk software bajakan sebesar 35,1 miliar. Berdasarkan kerugian tersebut dapat dilihat bahwa kerugian dari produk fashion tiruan lebih besar dari produk software bajakan, sehingga hal tersebut menunjukkan bahwa produk fashion tiruan lebih diminati oleh sebagian masyarakat, serta peredarannya cukup besar di Indonesia.

\section{S I M P U L A N}

Berdasarkan hasil analisis statistik dan pembahasan yang telah dilakukan, disimpulkan bahwa terdapat pengaruh yang signifikan antara kerentanan konsumen terhadap intensi membeli produk fashion tiruan dengan sikap atas produk tiruan sebagai mediator, dengan demikian hipotesis alternatif $\left(\mathrm{H}_{\mathrm{a}}\right)$ diterima. Kemudian diketahui bahwa arah pengaruh dari setiap variabel adalah positif, sehingga jika individu memiliki kerentanan konsumen yang tinggi, maka akan membentuk sikap individu untuk menyukai produk tiruan, yang kemudian sikap menyukai tersebut mendorong intensi individu untuk membeli produk fashion tiruan.

Penelitian selanjutnya diharapkan dapat meneliti faktor lainnya yang dapat memprediksi sikap maupun intensi membeli produk fashion tiruan, seperti value conciousness, integrity, collectivsm, risk assessment, status sosial, dan faktor demografi seperti pendapatan dan profesi. Penelitian selanjutnya juga diharapkan untuk meneliti perbedaan konsumen yang pernah membeli produk tiruan dan konsumen yang belum pernah membeli produk tiruan.

\section{U C A P A N T E R I MAKASIH}

Penulis mengucapkan terima kasih kepada seluruh pihak yang terlibat dalam membantu tercapainya penelitian ini antara lain, orang tua penulis, pengajar, rekan-rekan civitas akademik Fakultas Psikologi, Universitas Airlangga. Kemudian, kepada seluruh partisipan penelitian yang telah bersedia terlibat dalam penelitian ini, serta beberapa pihak terkait yang telah membantu selama proses penelitian hingga pengambilan data.

\section{DEKLARASI POTENSI TERJADINYAKONFLIK KEPENTINGAN}

Angger Agung Permadi dan Dewi Syarifah tidak bekerja, menjadi konsultan, memiliki saham, atau menerima dana dari perusahaan atau organisasi manapun yang mungkin akan mengambil untung dari diterbitkannya naskah ini.

\section{P UST AKA ACUA N}

Ajzen, I. (1991). The theory of planned behavior. Organizational Behavior and Human Decision Processes, 50(2), 179-211. https://doi.org/10.1016/0749-5978(91)90020-T 
Ajzen, I. (2005). Attitudes, Personality and Behaviour. McGraw-Hill Education (UK).

Al-Baroroh, H. R. (2019). PENGARUH EXPERIENTIAL MARKETING TERHADAP REVISIT INTENTION MELALUI CUSTOMER SATISFACTION PADA WAROENG DE'U DI NGANJUK [PhD Thesis]. University of Muhammadiyah Malang.

Andyna, A. S. (2020, Februari 15). Produk Palsu Semakin Merajalela, Brand Ternama Paling Banyak Ditiru. SINDOnews.com. https://lifestyle.sindonews.com/berita/1527466/186/produk-palsusemakin-merajalela-brand-ternama-paling-banyak-ditiru

Bearden, W. O., Netemeyer, R. G., \& Teel, J. E. (1989). Measurement of Consumer Susceptibility to Interpersonal Influence. Journal of Consumer Research, 15(4), 473. https://doi.org/10.1086/209186

Cheng, S.-I., \& Fu, H.-H. (2011). Examining Customer Purchase Intentions for Counterfeit Products Based on a Modified Theory of Planned Behavior. International Journal of Humanities and Social Science, 1(10), 7.

Chrisnawati, D., \& Sri, M. A. (2011). Faktor-Faktor Yang Mempengaruhi Perilaku Konsumtif Remaja Terhadap Pakaian. Jurnal Spirits, 2(1).

Efendi, J., \& Baidun, A. (2019). Faktor-Faktor Psikologis Yang Mempengaruhi Intensi Membeli Produk Fashion Tiruan. TAZKIYA: Journal of Psychology, 3(2). https://doi.org/10.15408/tazkiya.v20i2.9177

Fishbein, M., Ajzen, I., \& Flanders, N. A. (1975). Belief, Attitude, Intention, and Behavior: An Introduction to Theory and Research. Addison-Wesley Publishing Company.

Handayani, M. S. (2016, Mei 22). Barang Palsu: Membuat Rugi, Tapi juga Menghidupi-Tirto.ID. tirto.id. https://tirto.id/barang-palsu-membuat-rugi-tapi-juga-menghidupi-89R

Haqi, M. H. (2019). Gambaran Status Mental (Stres, Kecemasan, Dan Depresi) Pada Korban Pasca Gempa Berdasarkan Periode Perkembangan (Remaja, Dewasa, Dan Lansia) Di Desa Pendua Kabupaten Lombok Utara [PhD Thesis]. Universitas Airlangga.

Iskandar, S. R. (2015). Pengaruh susceptibility to interpersonal influence, kecerdasan emosi dan faktor demografi terhadap impulse buying pada remaja [B.S. thesis]. UIN Syarif Hidayatullah Jakarta: Fakultas Psikologi, 2015.

Kasuma, J., Noor, N. M., Abdurahman, A. Z. A., Sawangchai, A., \& Jemari, M. A. (2020). The Influence of Information Susceptibility and Normative Susceptibility on Counterfeit Manufacturing Products Purchase Intention. 9(2), 7.

Kemenperin. (2014, Agustus 4). Kerugian Akibat Peredaran Barang Palsu Capai Rp 65 T. Kemenperin.go.id. https://kemenperin.go.id/artikel/9703/

Lin, N.-H., \& Lin, B.-S. (2007). The Effect of Brand Image and Product Knowledge on Purchase Intention Moderated by Price Discount. Journal of International Management Studies, 12. 
MacKinnon, D. P., Fairchild, A. J., \& Fritz, M. S. (2007). Mediation Analysis. Annual Review of Psychology, 58(1), 593-614. https://doi.org/10.1146/annurev.psych.58.110405.085542

Matos, C. A. de, Ituassu, C. T., \& Rossi, C. A. V. (2007). Consumer attitudes toward counterfeits: A review and extension. Journal of Consumer Marketing, 24(1), 36-47. https://doi.org/10.1108/07363760710720975

Neuman, W. L. (2007). Basics of Social Research: Qualitative and Quantitative Approaches. Pearson/Allyn and Bacon.

Pallant, J. (2016). SPSS Survival Manual, 6th Edition (6th Revised edition). Open University Press.

Preacher, K. J., \& Hayes, A. F. (2004). SPSS and SAS procedures for estimating indirect effects in simple mediation models. Behavior Research Methods, Instruments, \& Computers, 36(4), 717-731. https://doi.org/10.3758/BF03206553

Salahian, A. (2016). Presenting a Model to Explain the Intention of Purchasing Pirated VCDs/DVDs. International Journal of Psychology, 10(01), 51-81.

Sani, F., \& Nurtjahyanti, H. (2016). HUBUNGAN ANTARA CITRA DIRI DENGAN INTENSI MEMBELI PRODUK FASHION BERMEREK TIRUAN PADA MAHASISWA TAHUN PERTAMA FAKULTAS EKONOMIKA DAN BISNIS UNIVERSITAS DIPONEGORO. 5, 6.

Saputra, A. W. (2009). ANALISIS PENGARUH INFORMATIVE SUSCEPTIBILITY, NORMATIVE SUSCEPTIBILITY, VALUE CONSCIOUSNESS, INTEGRITY DAN PERSONAL GRATIFICATION TERHADAP MINAT BELI DVD BAJAKAN MELALUI ATTITUDE TOWARDS PIRACY [Skripsi, UNIVERSITAS AIRLANGGA]. http://lib.unair.ac.id

Siham, M., \& Pierre, V.-F. (2012). THE EFFECTS OF COUNTERFEIT ON LUXURY BRAND BUYING BEHAVIOR, IN TERMS OF CONSUMPTION EXPERIENCE. 15.

Ting, M.-S., Goh, Y.-N., \& Isa, S. M. (2016). Determining consumer purchase intentions toward counterfeit luxury goods in Malaysia. Asia Pacific Management Review, 21(4), 219-230. https://doi.org/10.1016/j.apmrv.2016.07.003

Wang, F., Zhang, H., Zang, H., \& Ouyang, M. (2005). Purchasing pirated software: An initial examination of Chinese consumers. Journal of Consumer Marketing, 22(6), 340-351. https://doi.org/10.1108/07363760510623939

Yudiaatmaja, F. (2021). Analisis Jalur (Perhitungan Manual dan Aplikasi Komputer Statistik)—Rajawali Pers. PT. RajaGrafindo Persada. 